Archive for

Organic Chemistry

Arkivoc 2020, part iii, 90-102

\title{
Auxiliary-controlled diastereoselective synthesis of a syn C-6-epimer of the ADAM 10 inhibitor GI254023X
}

\author{
Shankari Nair, a, b, c Jan Rijn Zeevaart, ${ }^{b}$ and Roger Hunter*c \\ ${ }^{a}$ Radiation Biophysics Division, Department of Nuclear Medicine, iThemba LABS, Cape Town 7131, South Africa \\ ${ }^{b}$ Department of Radiochemistry, South African Nuclear Energy Corporation, Pretoria, 0001, South Africa \\ ${ }^{c}$ Department of Chemistry, University of Cape Town, Cape Town, 7700, South Africa \\ Email: roger.hunter@uct.ac.za
}

Received 06-02-2020

Accepted 08-10-2020

Published on line $08-25-2020$

\section{Abstract}

ADAM10 is a cell surface-expressed metalloprotease involved in various cell adhesion and proteolytic processes, in which biological studies have linked an over-expression of ADAM10 to the development and progression of various types of diseases including cancer. GI254023X is a hydroxamate metalloprotease inhibitor known for ADAM10 activity inhibition, but for which structure-activity based biological information for assessing anti-tumour and anti-inflammatory activity is lacking. In this work, an Evans' asymmetric boron aldol reaction was used to synthesise a syn C-6-epimer of GI254023X intended for biological evaluation against the natural inhibitor.
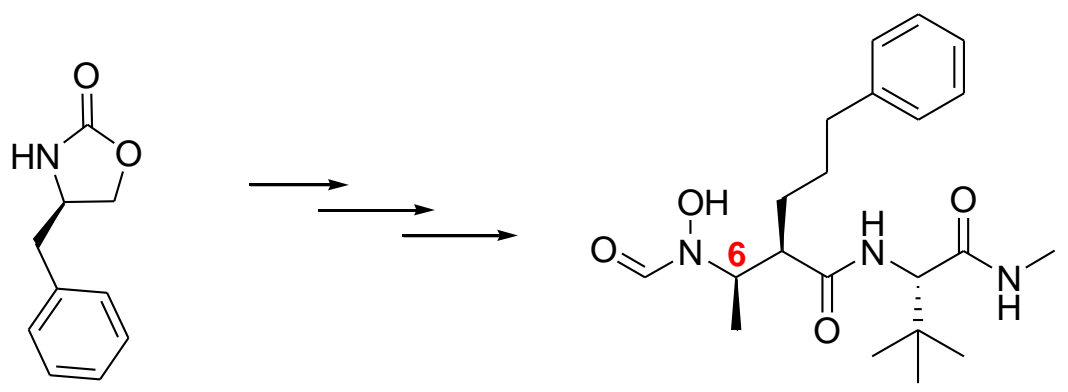

(R)-4-benzyloxazolidin-2-one

Keywords: ADAM10, boron enolates, Evans auxiliary, GI254023X, oxazolidinone 


\section{Introduction}

The cell surface-expressed metalloprotease, ADAM10 ( $\underline{\text { A }}$ Disintegrin and Metalloproteinase Domain-containing protein 10), is a member of the ADAM metalloprotease family and plays a vital role in cell adhesion and proteolytic processes of the ectodomain of various cell surface receptors and signalling molecules. ${ }^{1,2}$ Disruption of ADAM10 activity can lead to the development of various diseases such as Alzheimer's, asthma, cardiovascular disease, inflammatory diseases, and cancer, and drugs that modulate this protein are desirable. ${ }^{1}$ GI254023X (Figure 1) is a peptide-based ADAM10 inhibitor that possesses almost a 100-fold selectivity for ADAM10 versus other ADAMs and has been used extensively as a reference for various ADAM10 specific cell-uptake and inhibition studies. ${ }^{3,4}$ GlaxoSmithKline (GSK) disclosed the synthesis of GI254023X and its analogues in a patent in 2000 without providing any specific synthesis data for GI254023X stereoisomers, nor structure-activity relationship IC $\mathrm{C}_{50}$ data for $\mathrm{GI} 254023 \mathrm{X}$ derivatives in general. ${ }^{3} \mathrm{GI} 254023 \mathrm{X}$ was discontinued thereafter but has since become a research tool as well as featuring in a number of patents regarding its use (together with derivatives) for treating infections. ${ }^{5,6}$ Schmidt et al. later reported on an improved synthesis for the synthesis of GI254023X in an overall yield of $38 \% .{ }^{7}$ This route was found to be more suitable than the GSK synthetic route because of cost effectiveness and the ease of handling of the required reagents. ${ }^{7}$ The only numbering system for GI254023X that has been offered is by Schmidt et al. as shown in Figure 1, which will be followed in this report. ${ }^{7}$

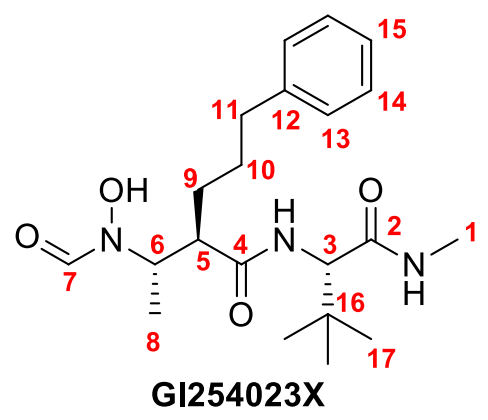

Figure 1. Structure and numbering system of the ADAM10 inhibitor, GI254023X. ${ }^{7}$

Most ADAM inhibitors possess a metal binding site for $\mathrm{Zn}^{2+}$ binding, which is normally at the inhibitor terminus and is typically in the form of an $\mathrm{N}$-formyl hydroxylamine moiety. ${ }^{2}$ From a synthesis perspective, the key structural features of GI254023X are the three stereogenic centres at C-3, C-5 and C-6, as well as the characteristic $\mathrm{N}$-formyl hydroxylamine functionality. The latter can occur in either $\mathrm{E}$ - (s-trans) or Z- (s-cis) configurations, which, together with the three centres of chirality, present four stereogenic elements that result in eight possible diastereomers of the inhibitor as racemates (sixteen stereoisomers in total). Analysis of the literature reveals that alkyl substituents are preferred at C-6, while the substituent at C-5 tolerates both alkyl and aryl groups for binding into the hydrophobic pocket of the enzyme (Figure 1). In addition, an $S$ stereogenicity is preferred at C-3, which ensures that the substituent faces away from the binding pocket of the enzyme and points towards the matrix solvent. Finally, a short alkyl group, such as a methyl, is favoured as the $\mathrm{N}$-alkyl substituent of the secondary amide at the $\mathrm{C}$-terminus. Importantly, as mentioned in the Introduction, no information in the GSK patent ${ }^{3}$ was given regarding the influence of the relative stereochemistry between C-5 and C- 6 on biological activity and hence SAR. Here, we recognised that there were three other diastereomeric C-5/C-6 possibilities to GI254023X and decided to initiate the SAR study by 
targeting the C-6 epimer, 12, as illustrated in Figure 2. The highlight of our synthesis was an efficient Evans' asymmetric syn-aldol, which allowed efficient construction of the C-5 and C- 6 stereogenic centres. The complete synthesis of $\mathbf{1 2}$ in chiral, non-racemic form is presented in this report.
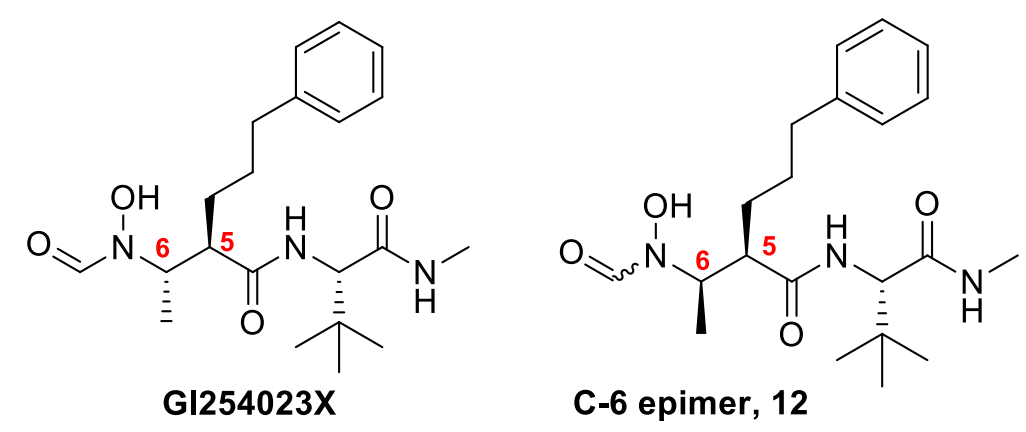

Figure 2. Structures of GI254023X and its C-6 epimer, the target of this study.

\section{Results and Discussion}

Oxazolidinone auxiliaries, popularly known as Evans' auxiliaries, ${ }^{8}$ are well known for their role in creating C-C bonds via asymmetric induction and are frequently used in complex organic synthesis. ${ }^{9-12}$ Diastereoselective auxiliary methodology uses a chiral auxiliary to direct the diastereoselectivity of a reaction, which is then subsequently cleaved non-destructively to avoid racemisation. ${ }^{13}$ The oxazolidinone auxiliary may be synthesised from the reduction of an amino acid followed by carbamate formation. It is then $N$-acylated, usually via the oxazolidinone anion, to form the starting $N$-acyl oxazolidinone. A noteworthy disadvantage of chiral auxiliaries is the additional two steps needed to attach and remove the auxiliary, which can be a drawback in long complex synthetic routes. Nevertheless, the advantage of the high diastereoselectivity achieved often outweighs the inconvenience of the additional synthetic steps. The auxiliaries of Evans and its $\mathrm{N}$-acylimide derivatives have been extensively used in numerous highly diastereoselective reactions such as alkylations, aminations, azidations, brominations, conjugate additions, Diels-Alder reactions, hydroxylations, Michael additions, and, most importantly for this work, in asymmetric aldol reactions. ${ }^{8-13}$ Retrosynthetic analysis of target 12, bearing in mind that we wanted to retain as many of the steps of the GSK/Schmidt syntheses as possible, alerted us to the need for creating a syn-aldol fragment as shown in Scheme 1, for which we chose an asymmetric Evans' aldol reaction using a boron enolate. ${ }^{3,7}$ We were aware that the antidiastereoselective alkylation of methyl $(R)$-3-hydroxybutyrate as used in the GSK and Schmidt syntheses was not applicable to the synthesis of this fragment. The Evans' boron enolate methodology achieves a highly efficient simple diastereoselectivity of the $\mathrm{HO} / \mathrm{CH}_{3}$ groups as syn- via intermediary of a (Z)-boron enolate. ${ }^{14}$ Furthermore, a high anti-diastereoselectivity is achieved between the auxiliary stereogenic centre and the aldol pair. This is discussed in a later section and is due to conformational preferences of the auxiliary in conjunction with a tight Zimmerman-Traxler (Z-T) transition state involving a short B-O bond. The key steps of our strategy are given in a general form in Scheme 1, in which it should be noted that an inversion of configuration at C-6 was required later on in the sequence. 


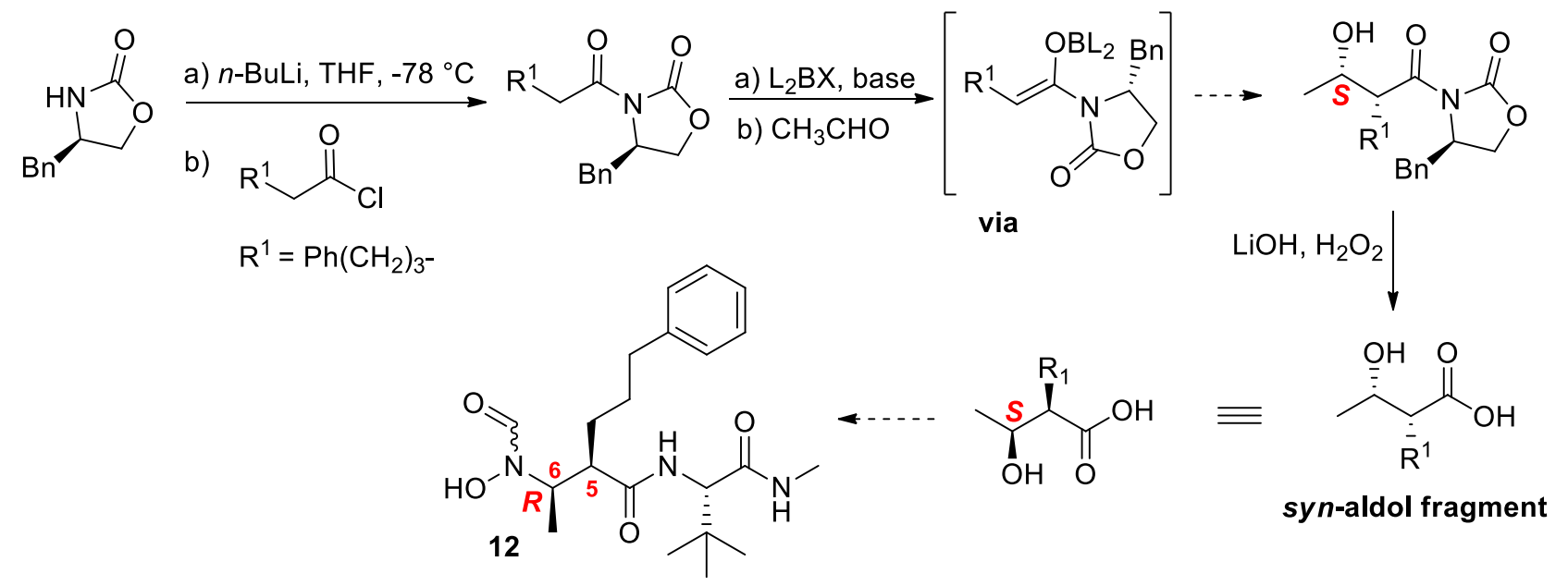

Scheme 1. The Evans' boron-aldol strategy used for 12.

First, the required $(R)$-auxiliary $((R)$-4-benzyloxazolidin-2-one) was prepared according to the method reported according to Evans et al., starting from the unnatural amino acid D-phenylalanine, which was first reduced using $\mathrm{LiAlH}_{4}$ to the amino alcohol as shown in Scheme 2 followed by cyclisation with diethyl carbonate to produce $(R)$-4-benzyloxazolidin-2-one, $1 .{ }^{15}$ The spectral data of 1 as well as its specific rotation of $\left([\alpha]_{D}^{20}=+\right.$ $66.8^{\circ},\left(\mathrm{CH}_{2} \mathrm{Cl}_{2}, c=1\right)$; lit. $\left([\alpha]_{D}^{20}=+68^{\circ},\left(\mathrm{CHCl}_{3}, c=1\right)\right)$, corresponded extremely well with literature values. ${ }^{15}$

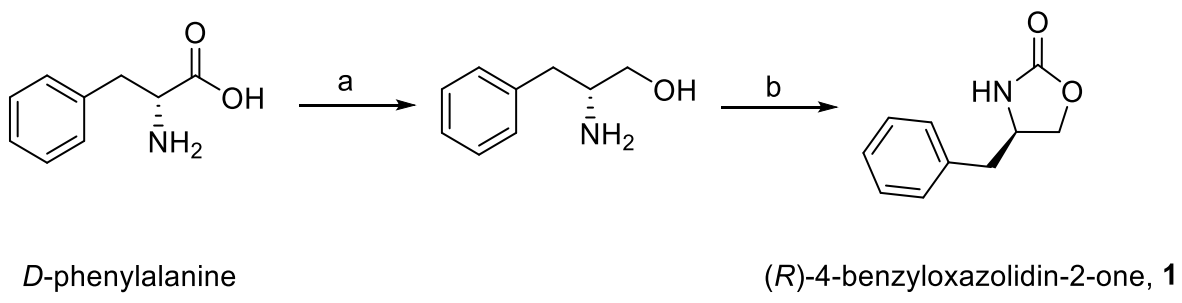

Scheme 2. Reagents and conditions: (a) $\mathrm{LiAlH}_{4}, \mathrm{THF}, 0{ }^{\circ} \mathrm{C}$ to reflux, $97 \%$; (b) Diethyl carbonate, $\mathrm{K}_{2} \mathrm{CO}_{3}, 135{ }^{\circ} \mathrm{C}$, $69 \%$.

The next step involved the attachment of the Evans' auxiliary (Scheme 3) via its anion to 5phenylpentanoyl chloride, 2, (produced from the reaction of 5-phenylpentanoic acid with thionyl chloride), to produce 3 , which was then reacted with dibutylboron triflate and triethylamine, followed by acetaldehyde to generate the diastereomerically pure secondary alcohol in chiral, non-racemic form, 4 , in a $90 \%$ isolated yield by chromatography. The ${ }^{1} \mathrm{H}$ NMR and ${ }^{13} \mathrm{C}$ spectral data of $\mathbf{4}$ indicated a single diastereomer, whose spectral data correlated to what was expected with a doublet at $1.23 \mathrm{ppm}$ for the newly introduced methyl group and ten protons for the two aromatic rings, as well as 19 singlet resonances in the ${ }^{13} \mathrm{C}$ spectrum. In addition, HRMS data were acceptable: (ES): Found 382.2040; calc. 382.2035 for $\mathrm{C}_{23} \mathrm{H}_{28} \mathrm{NO}_{4}(\mathrm{M}+\mathrm{H})^{+}$. The absolute aldol stereochemistry of $\mathbf{4}$ was taken to be in accordance with the stereoselectivity model as laid out by the Evans' model. ${ }^{8,9,14}$ 


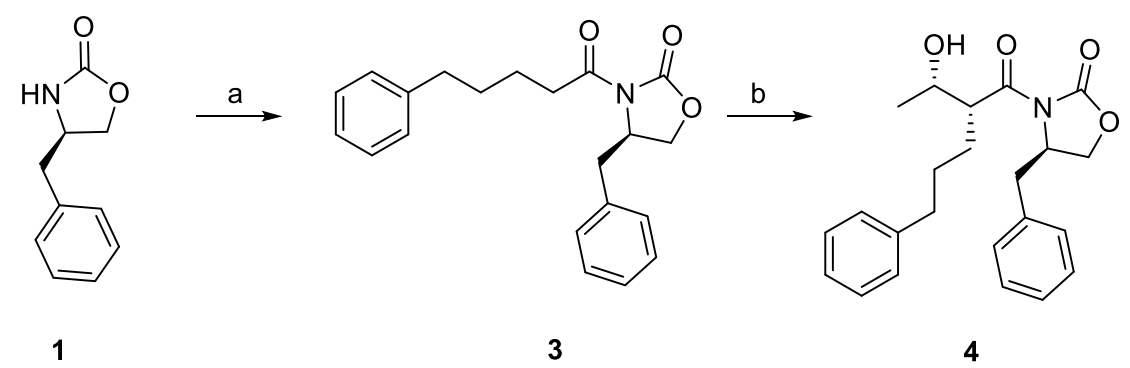

Scheme 3. Reagents and conditions: a) (i) $n$-BuLi, THF, $-78-0{ }^{\circ} \mathrm{C}$, (ii) 5-Phenylpentanoyl chloride (2), 70\%; b) (i) $\mathrm{Bu}_{2} \mathrm{BOTf}, \mathrm{Et}_{3} \mathrm{~N}, \mathrm{DCM}, 0^{\circ} \mathrm{C}$, (ii) $\mathrm{CH}_{3} \mathrm{CHO},-78^{\circ} \mathrm{C}, 90 \%$.

Regarding a rationalisation of overall diastereoselectivity, the methodology typically leads to high vicinal diastereoselectivity, producing only the syn-aldol product due to the short B-C and B-O bonds that form a tight six-membered Zimmerman-Traxler (Z-T) transition state. Specifically, reaction of the $\mathrm{N}$-acyl oxazolidinone $\mathbf{3}$ with di- $n$-butylboron triflate and triethylamine as base forms the (Z)-boron enolate virtually exclusively, in which the auxiliary adopts a chelated s-cis conformation as shown by the first structure in Scheme 4 . On addition of the aldehyde, the boron preferentially forms a chelated Z-T transition state, with the aldehyde forcing the auxiliary into a lower-energy s-trans conformation as shown in the Scheme. Importantly, in the absence of an auxiliary, a (Z)-enolate produces two syn diastereomers in equal amounts as a racemate via two enantiomeric chairs. Introduction of the Evans' auxiliary, however, results in a bias for one of the two now diastereoisomeric chairs in the Z-T transition state in which having the large benzyl group of the auxiliary pointing away from the six-membered ring is lower in energy compared to having it hovering over the ring (the auxiliary obligatorily adopts a pseudo-axial configuration). This results in a diastereofacial bias that leads, in this case, to preferential formation of the Evans' syn-aldol diastereomer 4 as shown. This contrasts with formation of the other possibility, the non-Evans diastereomer 4', as shown in Scheme 4, each stereoisomer drawn with the auxiliary as its s-cis ${ }_{\mathrm{CN}}$ conformer. ${ }^{16}$
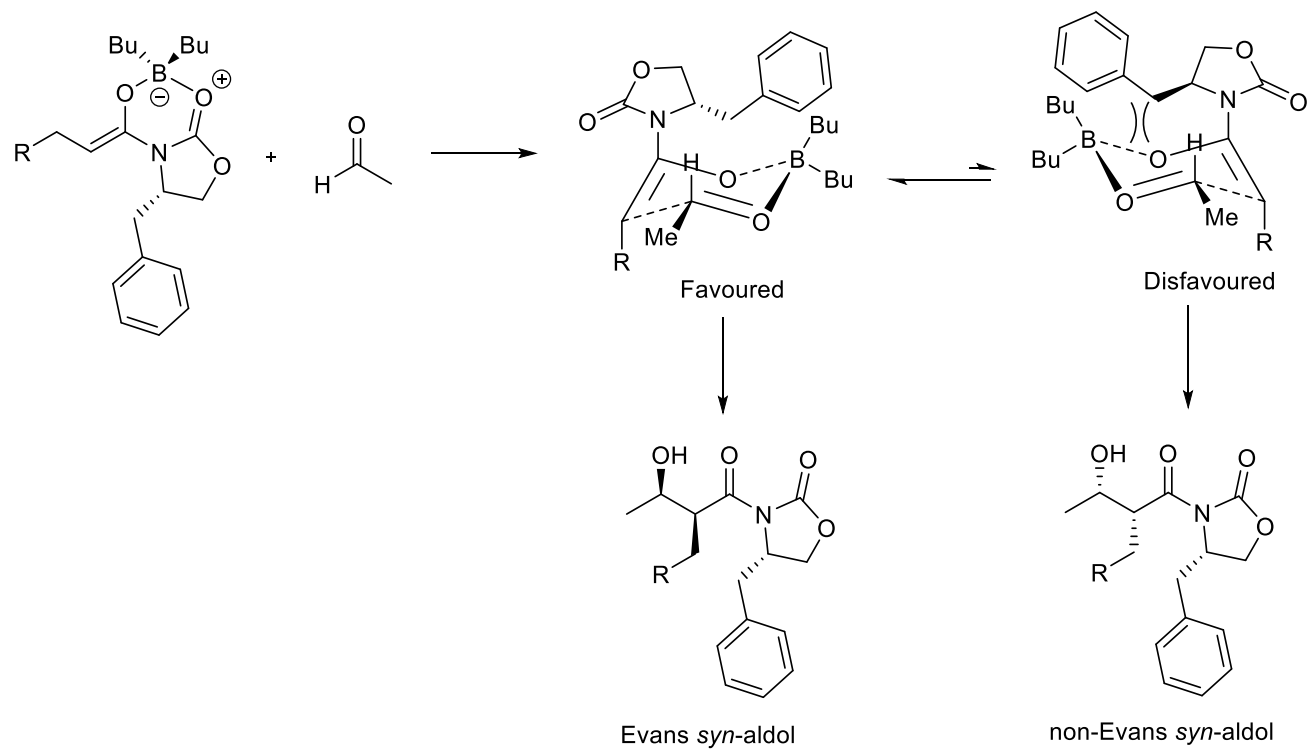

Scheme 4. Directing effect of the Evans' chiral auxiliary in the aldol reaction. 
Once the auxiliary was removed using lithium hydroperoxide ( $\mathrm{LiOOH}$ was generated by $\mathrm{LiOH}$ and $\mathrm{H}_{2} \mathrm{O}_{2}$ ) to produce acid 5, the remaining steps of the synthetic sequence were executed selecting options from the GSK and Schmidt syntheses that were appropriate to us. ${ }^{3,7}$ This involved first subjecting $\mathbf{5}$ to an amide coupling with $O$-benzylhydroxylamine and DCC (replacing EDC) to produce 6 (Scheme 5), in which the use of a benzyl protecting group as in Schmidt et al. was preferred to a THP group as used in the original GSK synthesis. ${ }^{3}$ Alcohol 6 was then subjected to a two-step sequence involving first conversion of the secondary hydroxyl group into its mesylate (with methanesulfonyl chloride and pyridine), followed by cyclisation in refluxing acetone with potassium carbonate to form the $\beta$-lactam (7) via nucleophilic substitution involving the hydroxamate nitrogen, softened by the presence of the hydroxyl group via the $\alpha$-effect. ${ }^{17}$ Lactam formation resulted in an $S_{N} 2$ inversion of configuration at $C-4$ of the $\beta$-lactam (for $\beta$-lactam numbering, see Scheme 5), from an $S$-configuration in 6 to an $R$-configuration in $\mathbf{7}$ as depicted in the Scheme, effectively establishing the correct C-5/6 stereochemical relationship in 12 ultimately. Expansion of the 3.17-3.25 ppm signal for $\mathrm{H}-4$ of 7 revealed a dq with $J=2.0,6.1 \mathrm{~Hz}$ vicinal couplings, confirming the trans-relative stereochemistry between $\mathrm{H}-3$ and $\mathrm{H}-4$ of 7 based on a near $90^{\circ}$ dihedral angle and, hence, a low vicinal $J$ value $(2.0 \mathrm{~Hz})$. The absolute stereochemistry, in our case, was assigned on the basis of Evans' model for a (Z)-boron enolate bearing a chiral oxazolidinone auxiliary.

The lactam ring was then opened using $1 \mathrm{M}$ sodium hydroxide in 1,4-dioxane to generate acid 8 (Scheme 5). $\mathrm{N}$-formylation using formic acetic anhydride and pyridine as in the GSK synthesis (rather than using $N$ formylbenzotriazole as in Schmidt et al.) then produced 9 in a $82 \%$ yield as a single geometrical isomer according to its ${ }^{1} \mathrm{H}$ NMR spectrum, in which a single $N$-formyl singlet resonating at 8.15 ppm for the formyl proton was observed. ${ }^{3,7}$

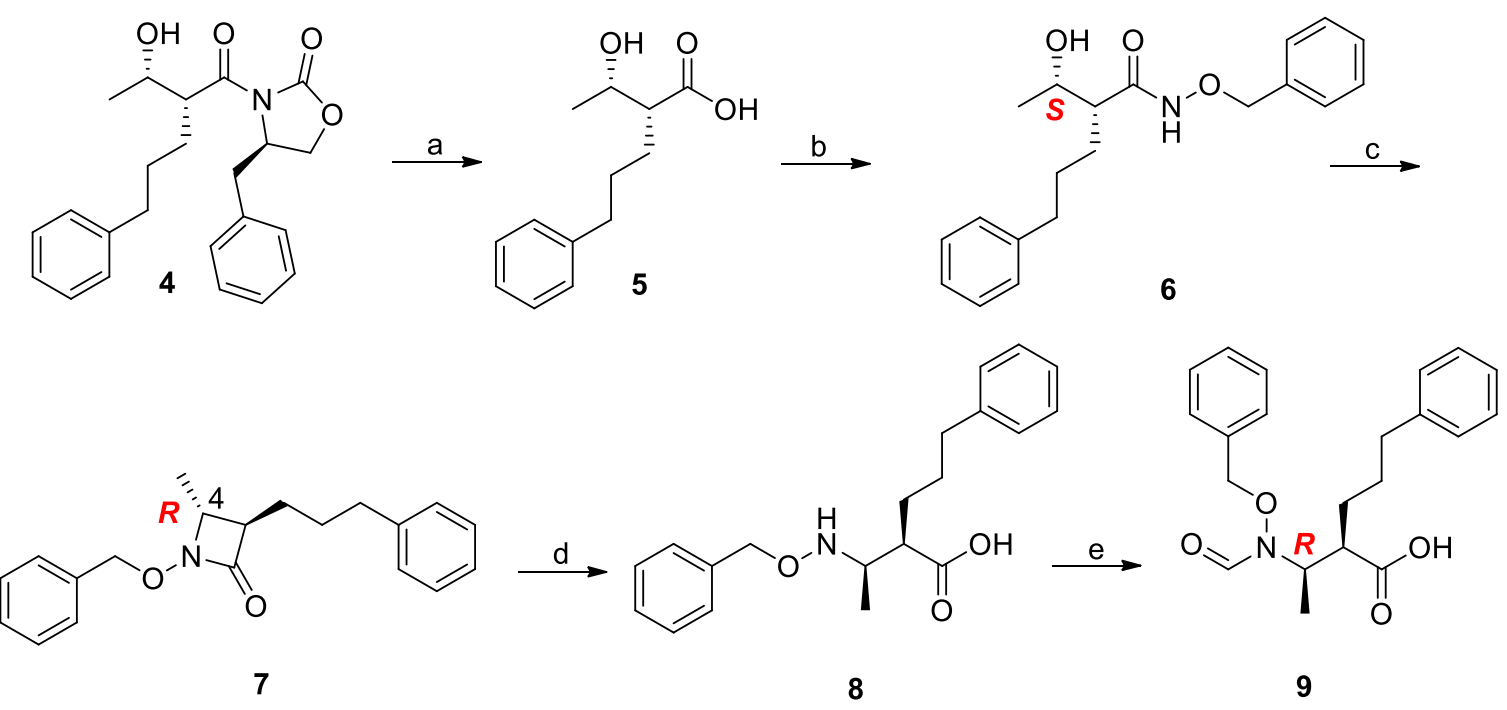

Scheme 5. Reagents and conditions: a) $\mathrm{LiOH}, \mathrm{H}_{2} \mathrm{O}_{2}, \mathrm{THF}: \mathrm{H}_{2} \mathrm{O}, 0{ }^{\circ} \mathrm{C}, 88 \%$; b) O-benzylhydroxylamine, DCC, $\mathrm{HOBt}$, DMAP, DCM, $0{ }^{\circ} \mathrm{C}-\mathrm{rt}, 71 \%$. c) i) $\mathrm{MsCl}$, pyridine, $\mathrm{DCM},-40{ }^{\circ} \mathrm{C}$, ii) $\mathrm{K}_{2} \mathrm{CO}_{3}$, acetone, reflux, $68 \%$; d) $1 \mathrm{M} \mathrm{NaOH}$, dioxane, rt, $75 \%$; e) Formic acetic anhydride, pyridine, $\mathrm{THF},-10^{\circ} \mathrm{C}, 82 \%$.

For the end-product, first, L-tert-leucine $\mathrm{N}$-methylamide, $\mathbf{1 0}$, was prepared in two steps from commercially available L-tert-leucine using a Boc-protection coupling and deprotection sequence as reported in the original GSK synthesis (Scheme 6). . $^{3,18}$ 


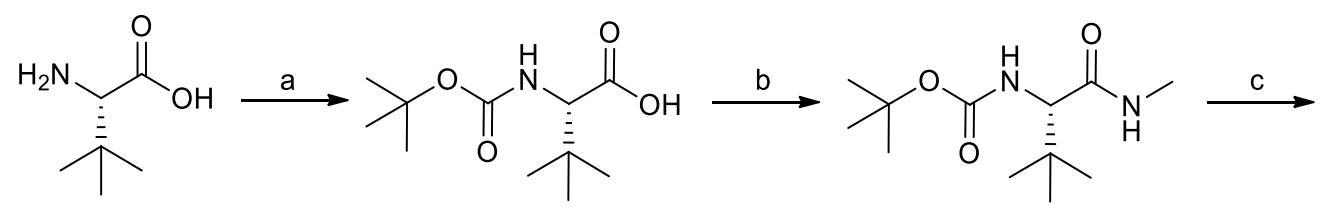

L-tert-leucine

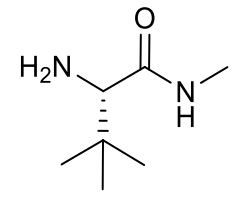

10

Scheme 6. Reagents and conditions: (a) $\mathrm{Boc}_{2} \mathrm{O}, \mathrm{KOH}$, THF: $\mathrm{H}_{2} \mathrm{O}, \mathrm{rt}, 87 \%$; (b) $\mathrm{EDC} . \mathrm{HCl}, \mathrm{HOBt}, \mathrm{Et}_{3} \mathrm{~N}, \mathrm{H}_{2} \mathrm{CNH}_{2} . \mathrm{HCl}$, DCM $0{ }^{\circ} \mathrm{C}-\mathrm{rt}, 90 \%$; (c) TFA, DCM, $0{ }^{\circ} \mathrm{C}, 86 \%$.

Finally, L-tert-leucine $\mathrm{N}$-methyl amide (10) and 9 were coupled together using DCC, HOBt, and catalytic DMAP in dichloromethane to furnish $\mathbf{1 1}$ in a 65\% isolated yield and as a single geometrical isomer, unlike that reported in Schmidt et al. (GI254023X series), which was reported as a mixture. ${ }^{7}$ Finally, 11 was subjected to hydrogenolysis of its benzyl protecting group using palladium-over-carbon in anhydrous methanol saturated with hydrogen to produce target 12 in a 97\% isolated yield (> 96\% purity by HPLC - see the Experimental), Scheme 7. The overall yield of the synthesis from compound 3 was 15\%. Target 12 was isolated as a 5:2 mixture of hydroxamate geometrical isomers according to ${ }^{1} \mathrm{H}$ NMR spectral analysis, which also showed the loss of the benzyl protecting group. Release of steric strain around the hydroxamate presumably resulted in scrambling of the s-cis and s-trans geometrical isomers around the hydroxamate axis. This was also observed in the ${ }^{13} \mathrm{C}$ NMR spectrum of 12 in which a doubling of resonances for the formyl carbon C-7 could be seen this was also observed in the Schmidt ${ }^{13} \mathrm{C}$ NMR data for GI254023X. ${ }^{7}$ A comparison of both the ${ }^{1} \mathrm{H}$ and ${ }^{13} \mathrm{C}$ NMR data of 12 from this work to the Schmidt and the GSK data for GI254023X showed changes in and around the C-5/C-6 resonances that supported that we had synthesised a GI254023X C-5/C-6 epimer (see the assignments in the Experimental). Our studies on the biology activity of $\mathbf{1 2}$ in relation to that of GI254023X will be reported in a subsequent paper.

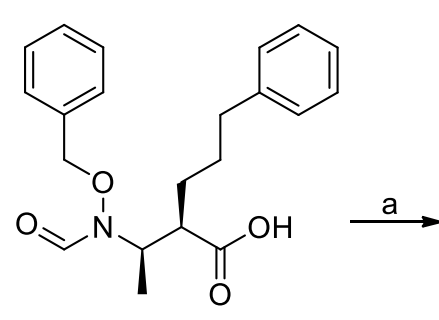

9

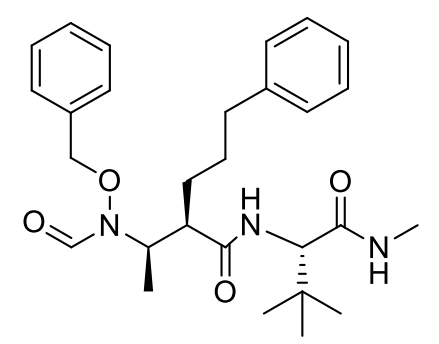

11

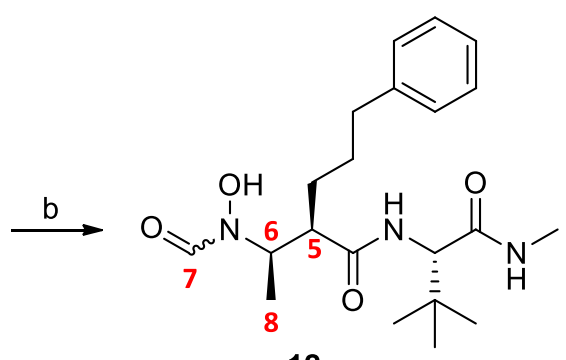

12

Scheme 7. Reagents and Conditions: (a) 10, DCC, HOBt, DMAP, $0{ }^{\circ} \mathrm{C}-\mathrm{rt}, 65 \%$; (b) Pd/C, $\mathrm{H}_{2}, \mathrm{rt}, 97 \%$.

\section{Conclusions}

In summary, we have successfully synthesised a syn C-6-epimer of GI254023X, compound 12, using Evans synaldol boron enolate methodology for the key step. Future work will assess the influence of the $\mathrm{C}-5 / \mathrm{C}-6$ relative stereochemistry on the biological activity against ADAM10. 


\section{Experimental Section}

General. All reagents were available from commercial sources (Sigma-Aldrich, Merck) and were used without further purification. All solvents were freshly distilled. All reactions were performed under a nitrogen atmosphere; unless stated otherwise. Reaction progress were monitored by thin layer chromatography (TLC) using aluminium backed silica-gel $60 \mathrm{~F}_{254}$ plates and was observed using both ultraviolet and fluorescent light or spraying with a $2.5 \%$ solution of anisaldehyde in a mixture of sulfuric acid and ethanol (1:10 v/v). Column chromatography was carried out using Kieselgel 60 silica gel. Melting points were determined using a ReichertHung Thermovar Hot Stage Microscope and are uncorrected. Optical rotations were obtained using a Perkin Elmer 343 polarimeter at $589 \mathrm{~nm}$ and $20^{\circ} \mathrm{C}$ in which the concentration $c$, refers to g/100 mL. Infrared (IR) absorptions were measured on a Perkin-Elmer Spectrum $100 \mathrm{FT}$-IR Spectrometer as $\mathrm{KBr}$ pellets or using a Nicolet 380 FT-IR-Spectrometer equipped with a SMART iTR ATR unit. ${ }^{1} \mathrm{H}$ Nuclear Magnetic Resonance spectra were recorded on a Bruker $300 \mathrm{MHz}\left(75 \mathrm{MHz}\right.$ for $\left.{ }^{13} \mathrm{C}\right)$ or $400 \mathrm{MHz}\left(101 \mathrm{MHz}\right.$ for $\left.{ }^{13} \mathrm{C}\right)$ instrument. The chemical shifts $(\delta)$ in ppm of the deuterated solvents used were, $\mathrm{CDCl}_{3}$ (7.26 in ${ }^{1} \mathrm{H}$ NMR and 77.16 in $\left.{ }^{13} \mathrm{CNMR}\right), \mathrm{CD}_{3} \mathrm{OD}$ (3.31 in ${ }^{1} \mathrm{H} \mathrm{NMR}$ and 49.20 in ${ }^{13} \mathrm{C}$ NMR). Chemical shifts $(\delta)$ are reported in ppm and $J$ values in $\mathrm{Hz}$. Electrospray mass spectra (ES-MS) were recorded on a JEOL GCmatell mass spectrometer. High performance liquid chromatography (HPLC) was carried out on an Agilent Technologies 1220 Infinity LC (G4288C) with a C18 reverse phase column in HPLC grade acetonitrile (ACN) and double distilled de-ionised Millipore ${ }^{\circledR}$ Direct- $Q$ water. Chiral HPLC was performed on an Agilent 1220 Series using a Diacel Chiracel OD $(250 \times 4.6 \mathrm{~mm})$ or Chiralpak AD $(250 \times 4.6 \mathrm{~mm})$ column in HPLC grade isopropanol ( $i$-PrOH) and hexane (Hex). Elemental analyses were recorded using a Fisons EA 1108 CHNS elemental analyser.

(R)-4-Benzyloxazolidin-2-one (1). ${ }^{15,19}$ To a stirred slurry of $\mathrm{LiAlH}_{4}(2.05 \mathrm{~g}, 54.0 \mathrm{mmol})$ in THF $(0.2 \mathrm{M})$ at $0{ }^{\circ} \mathrm{C}$, was added D-phenylalanine $(4.00 \mathrm{~g}, 24.2 \mathrm{mmol})$ over a period of $30 \mathrm{~min}$. The solution was kept at this temperature for $1 \mathrm{hr}$ after which it was refluxed for $12 \mathrm{hr}$ and then cooled to $0{ }^{\circ} \mathrm{C} ; 1 \mathrm{M} \mathrm{NaOH}(12.8 \mathrm{~mL})$ and $\mathrm{H}_{2} \mathrm{O}(16 \mathrm{~mL})$ were added and the mixture stirred for $1 \mathrm{hr}$ at this temperature. The salts were filtered through Celite and the filtrate extracted with EtOAc $(3 \times 50 \mathrm{~mL})$. The combined organic layers were washed with sat. $\mathrm{NaCl}$ and filtered over $\mathrm{MgSO}_{4}$ to produce a solid after solvent evaporation. Thereafter, $4.50 \mathrm{~g}, 30.0 \mathrm{mmol}$ of the solid, anhydrous $\mathrm{K}_{2} \mathrm{CO}_{3}(0.414 \mathrm{~g}, 2.99 \mathrm{mmol})$ and diethyl carbonate $(7.3 \mathrm{~mL}, 60.0 \mathrm{mmol})$ were added to a two-necked round-bottomed flask that was placed in ice, fitted with a distillation head to collect the EtOH produced, and a condenser and receiving flask. The mixture was heated to $115{ }^{\circ} \mathrm{C}$ until TLC showed the disappearance of the starting material. The reaction mixture was cooled to room temperature, diluted with DCM and washed successively with sat. $\mathrm{NaHCO}_{3}$, water and sat. $\mathrm{NaCl}$. The combined organic layers were filtered over $\mathrm{MgSO}_{4}$ and reduced and purified by flash chromatography to give $1(3.65 \mathrm{~g}, 69 \%)$ as a white solid. Mp $88-90^{\circ} \mathrm{C}$ (Lit. Mp $\left.88-90^{\circ} \mathrm{C}\right) ;[\alpha]_{D}^{20}=+66.8^{\circ},\left(\mathrm{CH}_{2} \mathrm{Cl}_{2}, \mathrm{c}=1\right)\left(\mathrm{Lit}[\alpha]_{D}^{18}=+64^{\circ},\left(\mathrm{CHCl}_{3}, \mathrm{c}=1\right)^{20} ; \mathrm{IR} v_{\max }(\mathrm{KBr})\right.$ $/ \mathrm{cm}^{-1} 1746(\mathrm{C}=\mathrm{O}), 3275(\mathrm{NH}) ; \delta_{\mathrm{H}}\left(300 \mathrm{MHz}, \mathrm{CDCl}_{3}\right) 2.74-2.79(\mathrm{~m}, 1 \mathrm{H}), 2.82-2.88(\mathrm{~m}, 1 \mathrm{H}), 3.99-4.07(\mathrm{~m}, 2 \mathrm{H})$, $4.30-4.34(\mathrm{~m}, 1 \mathrm{H}), 6.24(\mathrm{br} \mathrm{s}, 1 \mathrm{H}), 7.10-7.28(\mathrm{~m}, 5 \mathrm{H}) ; \delta_{\mathrm{C}}\left(101 \mathrm{MHz}, \mathrm{CDCl}_{3}\right) 41.3,53.7,69.5,127.1,128.9$, $129.1,136.0,159.7 .^{15}$

5-Phenylpentanoyl chloride (2). ${ }^{21}$ 5-Phenylpentanoic acid $(10.0 \mathrm{~g}, 56.1 \mathrm{mmol})$ in $\mathrm{SOCl}_{2}(20 \mathrm{~mL})$ was refluxed overnight, after which excess $\mathrm{SOCl}_{2}$ was removed via distillation under nitrogen at atmospheric pressure, and the crude residue further purified by distillation in vacuo $(\approx 10 \mathrm{mmHg})$ gave $2(8.25 \mathrm{~g}, 97 \%)$ as a yellow oil. $\mathrm{R}_{f}$ (Hex/EtOAc 5:5) 0.72; $\delta_{\mathrm{H}}\left(300 \mathrm{MHz}, \mathrm{CDCl}_{3}\right) 1.74-1.86(\mathrm{~m}, 4 \mathrm{H}), 2.72(\mathrm{t}, J 7.1 \mathrm{~Hz}, 2 \mathrm{H}), 2.96(\mathrm{t}, J 7.1 \mathrm{~Hz}, 2 \mathrm{H}), 7.25$ $-7.40(\mathrm{~m}, 5 \mathrm{H}) ; \delta_{\mathrm{C}}\left(101 \mathrm{MHz}, \mathrm{CDCl}_{3}\right) 24.6,30.0,35.3,46.9,126.0,128.4,128.4,141.5,173.5$. 
(R)-4-Benzyl-3-(5-phenylpentanoyl)oxazolidin-2-one (3). $n$-BuLi (1.6 M, $19.5 \mathrm{~mL}, 31.0 \mathrm{mmol}$ ) was added to a solution of $(R)$-4-benzyloxazolidin-2-one $(5.00 \mathrm{~g}, 28.2 \mathrm{mmol})$ in THF $(0.3 \mathrm{M})$ at $-78^{\circ} \mathrm{C}$. After $30 \mathrm{~min}$ at this temperature, 2 ( $1.1 \mathrm{eq}$ ) was added and the reaction was stirred at $-78^{\circ} \mathrm{C}$ for $30 \mathrm{~min}$ and then allowed to warm to $0{ }^{\circ} \mathrm{C}$. After $12 \mathrm{hr}$ cold sat. $\mathrm{NH}_{4} \mathrm{Cl}$ was added, and the solution extracted with EtOAc $(3 \times 30 \mathrm{~mL})$, the combined organic layers were washed with cold sat. $\mathrm{NaHCO}_{3}$ followed by brine and then filtered over $\mathrm{MgSO}_{4}$. Following solvent removal, the residue was purified by flash chromatography to give 3 ( $6.53 \mathrm{~g}, 70 \%)$ as a white solid (recrystallised from diisopropyl ether). Mp $38-40^{\circ} \mathrm{C} ; \mathrm{R}_{f}(\mathrm{Hex} / \mathrm{EtOAc} 8: 2) 0.65 ;[\alpha]_{D}^{20}=-48.0^{\circ},\left(\mathrm{CH}_{2} \mathrm{Cl}_{2}, c=\right.$ 1); IR $v_{\max }(\mathrm{ATR}) / \mathrm{cm}^{-1} 1688,1741(2 \times \mathrm{C}=\mathrm{O}) ; \delta_{\mathrm{H}}\left(300 \mathrm{MHz}, \mathrm{CDCl}_{3}\right) 1.73-1.80(\mathrm{~m}, 4 \mathrm{H}), 2.68-2.73(\mathrm{~m}, 2 \mathrm{H}), 2.77$ (dd, J 9.5, $13.4 \mathrm{~Hz}, 1 \mathrm{H}), 2.97-3.04(\mathrm{~m}, 2 \mathrm{H}), 3.29$ (dd, J 3.3, $13.4 \mathrm{~Hz}, 1 \mathrm{H}), 4.14-4.19(\mathrm{~m}, 2 \mathrm{H}), 4.65-4.73(\mathrm{~m}$, $1 \mathrm{H}), 7.16-7.37(\mathrm{~m}, 10 \mathrm{H}) ; \delta_{\mathrm{C}}\left(101 \mathrm{MHz}, \mathrm{CDCl}_{3}\right)$ 24.0, 30.8, 35.4, 35.7, 37.9, 55.1, 66.2, 125.8, 127.3), 128.3, 128.4, 129.0, 129.4, 135.4, 142.2, 153.5, 173.2; Anal. Calc. for $\mathrm{C}_{21} \mathrm{H}_{23} \mathrm{NO}_{3}$ (\%): C, 74.75; $\mathrm{H}, 6.87 ; \mathrm{N}, 4.15 ;$ Found (\%): C, 74.80; H, 6.92; N, 4.07; HRMS (ES): Found 338.1778; calc. 338.1770 for $\mathrm{C}_{21} \mathrm{H}_{24} \mathrm{NO}_{3}(\mathrm{M}+\mathrm{H})^{+}$.

(R)-4-Benzyl-3-((R)-2-((S)-1-hydroxyethyl)-5-phenylpentanoyl)oxazolidin-2-one (4). Dibutylboron triflate $\left(\mathrm{Bu}_{2} \mathrm{BOTf}\right)(1.0 \mathrm{M}, 7.20 \mathrm{~mL}, 7.20 \mathrm{mmol})$ and freshly distilled $\mathrm{Et}_{3} \mathrm{~N}(1.10 \mathrm{~mL}, 7.71 \mathrm{mmol})$ was added dropwise to a solution of $3(2.00 \mathrm{~g}, 5.93 \mathrm{mmol})$ in $\mathrm{DCM}(0.3 \mathrm{M})$ under argon at $0{ }^{\circ} \mathrm{C}$. After $30 \mathrm{~min}$ at $0{ }^{\circ} \mathrm{C}$, the reaction mixture was cooled to $-78{ }^{\circ} \mathrm{C}$, and acetaldehyde $(0.70 \mathrm{~mL}, 12.0 \mathrm{mmol})$ was added dropwise. The solution was stirred at $-78{ }^{\circ} \mathrm{C}$ for a further $30 \mathrm{~min}$, and then warmed to $-10{ }^{\circ} \mathrm{C}$ overnight. Cold sat. $\mathrm{NaHCO}_{3}$ was added at 0 ${ }^{\circ} \mathrm{C}$ and the reaction mixture stirred for $20 \mathrm{~min}$, after which the DCM was removed in vacuo and the mixture extracted with EtOAc (three times). The organic layers were combined and filtered over $\mathrm{MgSO}_{4}, \mathrm{reduced}_{\text {and }}$ the residue purified by flash chromatography to give 4 (2.03 g, 90\%) as a yellow viscous oil. $\mathrm{R}_{f}$ (Hex/EtOAc 5:5) $0.48 ;[\alpha]_{D}^{20}=-11.2^{\circ},\left(\mathrm{CH}_{2} \mathrm{Cl}_{2}, c=1\right) ; \mathrm{IR} v_{\max }(\mathrm{ATR}) / \mathrm{cm}^{-1} 1692,1748(2 \times \mathrm{C}=0), 3448(\mathrm{O}-\mathrm{H}) ; \delta_{\mathrm{H}}\left(300 \mathrm{MHz}, \mathrm{CDCl}_{3}\right)$ $1.23(\mathrm{~d}, J 6.1 \mathrm{~Hz}, 3 \mathrm{H}), 1.63-1.74(\mathrm{~m}, 4 \mathrm{H}), 2.58-2.71(\mathrm{~m}, 2 \mathrm{H}), 2.76(\mathrm{dd}, J$ 9.5, $13.3 \mathrm{~Hz}, 1 \mathrm{H}), 3.34(\mathrm{dd}, J 3.3,13.3$ $\mathrm{Hz}, 1 \mathrm{H}), 4.10-4.26(\mathrm{~m}, 4 \mathrm{H}), 4.71-4.74(\mathrm{~m}, 1 \mathrm{H}), 7.17-7.35(\mathrm{~m}, 10 \mathrm{H}) ; \delta_{\mathrm{c}}\left(101 \mathrm{MHz}, \mathrm{CDCl}_{3}\right)$ 19.7, 27.4, 29.4, 36.0, 38.1, 48.6, 55.7, 66.1, 68.9, 125.9, 127.5, 128.5, 128.6, 129.1, 129.4, 135.3, 142.0, 153.9, 175.4; HRMS (ES): Found 382.2040; calc. 382.2035 for $\mathrm{C}_{23} \mathrm{H}_{28} \mathrm{NO}_{4}(\mathrm{M}+\mathrm{H})^{+}$.

(R)-2-((S)-1-Hydroxyethyl)-5-phenylpentanoic acid (5). To a solution of 4 (1.00 g, $2.62 \mathrm{mmol})$ in THF: $\mathrm{H}_{2} \mathrm{O}(4: 1$, $0.2 \mathrm{M})$ at $0{ }^{\circ} \mathrm{C}$ was added $30 \% \mathrm{H}_{2} \mathrm{O}_{2}(\mathrm{w} / \mathrm{w} ; 8.82 \mathrm{M})(0.60 \mathrm{~mL}, 5.24 \mathrm{mmol})$ dropwise, followed by a cold solution of $\mathrm{LiOH} . \mathrm{H}_{2} \mathrm{O}(0.18 \mathrm{~g}, 4.29 \mathrm{mmol})$ in distilled water $(1 \mathrm{M})$. The reaction was stirred for $1 \mathrm{hr}$ at $0{ }^{\circ} \mathrm{C}$, after which time cold sat. $\mathrm{Na}_{2} \mathrm{SO}_{3}$ was added to adjust the $\mathrm{pH}$ to $\mathrm{pH} 12$. The THF was removed in vacuo and the resulting aqueous layer extracted with DCM (three times) to extract the free auxiliary, which was filtered over anhydrous $\mathrm{MgSO}_{4}$ and concentrated in vacuo. The aqueous layer was cooled to $0{ }^{\circ} \mathrm{C}$ and acidified to $\mathrm{pH} 1$ with $6 \mathrm{M} \mathrm{HCl}$ and extracted to give $5(0.51 \mathrm{~g}, 88 \%)$ and was sufficiently pure by ${ }^{1} \mathrm{H}$ and ${ }^{13} \mathrm{C}$ NMR analysis and used in the next step without further purification. $\mathrm{R}_{f}$ (Hex/EtOAc 5:5) 0.30; $[\alpha]_{D}^{20}=+18.4^{\circ},\left(\mathrm{CH}_{2} \mathrm{Cl}_{2}, c=1\right)$; IR $v_{\max }(\mathrm{ATR})$ $/ \mathrm{cm}^{-1} 1740(\mathrm{C}=\mathrm{O}), 3194(\mathrm{OH}) ;\left(300 \mathrm{MHz}, \mathrm{CDCl}_{3}\right) 1.26(\mathrm{~d}, J 6.3 \mathrm{~Hz}, 3 \mathrm{H}), 1.53-1.82(\mathrm{~m}, 4 \mathrm{H}), 2.36(\mathrm{~m}, 1 \mathrm{H}), 2.58-$ $2.70(\mathrm{~m}, 2 \mathrm{H}), 3.94-4.02(\mathrm{~m}, 1 \mathrm{H}), 7.16-7.30(\mathrm{~m}, 5 \mathrm{H}), 7.93(\mathrm{br} \mathrm{s}, 1 \mathrm{H}) ; \delta_{\mathrm{C}}\left(101 \mathrm{MHz}, \mathrm{CDCl}_{3}\right)$ 17.8, 21.2, 29.2, 35.7, 50.8, 65.0, 126.0, 128.5, 128.5, 142.0, 178.9; HRMS (ES): Found 223.1176; calc. 223.1156 for $\mathrm{C}_{13} \mathrm{H}_{19} \mathrm{O}_{3}$ $(\mathrm{M}+\mathrm{H})^{+}$.

(R)-N-(Benzyloxy)-2-((S)-1-hydroxyethyl)-5-phenylpentanamide (6). To a solution of 5 (0.50 g, $2.25 \mathrm{mmol})$ in $\operatorname{DCM}(0.3 \mathrm{M})$ at $0{ }^{\circ} \mathrm{C}$ was added HOBt $(0.40 \mathrm{~g}, 2.93 \mathrm{mmol}), N, N^{\prime}$-dicyclohexylcarbodiimide (DCC) (0.60 g, 2.93 $\mathrm{mmol})$, O-benzylhydroxylamine $(0.40 \mathrm{~mL}, 3.34 \mathrm{mmol})$ and 4-dimethylaminopyridine (DMAP) (0.14 g, 1.13 $\mathrm{mmol})$. The reaction was allowed to warm to room temperature and stirred for a further $12 \mathrm{hr}$ before being 
filtered through Celite, the filtrate evaporated in vacuo and the residue subjected directly to column chromatography to afford $6(0.52 \mathrm{~g}, 71 \%)$ (recrystallised from $\mathrm{MeOH}$ and $\mathrm{H}_{2} \mathrm{O}$ ) as a solid. $\mathrm{Mp} 76-78{ }^{\circ} \mathrm{C} ; \mathrm{R}_{f}$ (Hex/EtOAc 5:5) 0.18; $[\alpha]_{D}^{20}=+14.9^{\circ},\left(\mathrm{CH}_{3} \mathrm{OH}, c=0.5\right)$; IR $v_{\max }(\mathrm{ATR}) / \mathrm{cm}^{-1} 1697(\mathrm{C}=\mathrm{O}), 3126(\mathrm{OH}) ; \delta_{\mathrm{H}}(300 \mathrm{MHz}$, $\left.\mathrm{CD}_{3} \mathrm{OD}\right) 1.09(\mathrm{~d}, J 6.2 \mathrm{~Hz}, 3 \mathrm{H}), 1.56-1.76(\mathrm{~m}, 4 \mathrm{H}), 2.16-2.26(\mathrm{~m}, 1 \mathrm{H}), 2.49-2.62(\mathrm{~m}, 2 \mathrm{H}), 3.68-3.76(\mathrm{~m}, 1 \mathrm{H})$, $4.82(\mathrm{~s}, 2 \mathrm{H}), 7.09-7.40(\mathrm{~m}, 10 \mathrm{H}) ; \delta_{\mathrm{C}}\left(101 \mathrm{MHz}, \mathrm{CD}_{3} \mathrm{OD}\right) 21.8,26.9,30.8,37.0,53.3,69.7,79.1,126.9,129.5$, 129.6, 129.6, 129.8, 130.4, 137.2, 143.7, 173.7; Anal. Calc. for $\mathrm{C}_{20} \mathrm{H}_{25} \mathrm{NO}_{3}$ (\%): C, 73.37; $\mathrm{H}, 7.07 ; \mathrm{N}, 4.28 ;$ Found (\%): C, 73.33; H, 7.05; N, 4.21; HRMS (ES): Found 328.1906; calc. 328.1908 for $\mathrm{C}_{20} \mathrm{H}_{26} \mathrm{NO}_{3}(\mathrm{M}+\mathrm{H})^{+}$.

(3R,4R)-1-(Benzyloxy)-4-methyl-3-(3-phenylpropyl)azetidin-2-one (7). A solution of methanesulfonyl chloride $(80 \mu \mathrm{L}, 1.01 \mathrm{mmol})$ and pyridine $(0.40 \mathrm{~mL}, 4.20 \mathrm{mmol})$ in DCM $(1 \mathrm{M})$ was added to a solution of 6 (0.25 g, 0.84 $\mathrm{mmol})$ in DCM $(0.3 \mathrm{M})$ at $-40{ }^{\circ} \mathrm{C}$. The reaction was warmed to $-10{ }^{\circ} \mathrm{C}$ and stirred at this temperature for a further $3 \mathrm{hr}$, at which time the reaction was diluted with $\mathrm{DCM}$ and washed with $1 \mathrm{M} \mathrm{HCl}$ and sat. $\mathrm{NaCl}$. The organic layer was filtereed over $\mathrm{MgSO}_{4}$ and concentrated in vacuo, before being subjected to column chromatography to give the mesylated intermediate as a yellow oil. A suspension of the mesylate $(0.34 \mathrm{~g}, 0.84$ $\mathrm{mmol}$ ) and anhydrous $\mathrm{K}_{2} \mathrm{CO}_{3}(0.23 \mathrm{~g}, 1.68 \mathrm{mmol})$ in acetone $(0.3 \mathrm{M})$ was then heated at reflux for $24 \mathrm{hr}$. The suspension was filtered, the filtrate concentrated in vacuo and purified by silica gel chromatography to give 7 (94.0 mg, 68\%) as a yellow oil. Rf (Hex/EtOAc 8:2) 0.81; $[\alpha]_{D}^{20}=-9.6^{\circ},\left(\mathrm{CH}_{2} \mathrm{Cl}_{2}, c=0.5\right) ; \mathrm{IR} v_{\max }(\mathrm{ATR}) / \mathrm{cm}^{-1} 1715$ $(\mathrm{C}=0) ; \delta_{\mathrm{H}}\left(300 \mathrm{MHz}, \mathrm{CDCl}_{3}\right) 1.16(\mathrm{~d}, J 6.1 \mathrm{~Hz}, 3 \mathrm{H}), 1.49-1.70(\mathrm{~m}, 4 \mathrm{H}), 2.39-2.43(\mathrm{~m}, 1 \mathrm{H}), 2.58-2.62(\mathrm{~m}, 2 \mathrm{H})$, $3.17-3.25(\mathrm{dq}, J 2.0,6.1 \mathrm{~Hz}, 1 \mathrm{H}), 4.83\left(\mathrm{~d}, J_{A B} 11.3 \mathrm{~Hz}, 1 \mathrm{H}\right), 4.88\left(\mathrm{~d}, J_{A B} 11.3 \mathrm{~Hz}, 1 \mathrm{H}\right), 7.12-7.39(\mathrm{~m}, 10 \mathrm{H}) ; \delta_{C}$ $\left(101 \mathrm{MHz} \mathrm{CDCl}_{3}\right)$ 17.6, 27.9, 29.1, 35.8, 52.8, 60.4, 78.3, 126.0, 128.5, 128.5, 128.7, 129.0, 129.4, 135.7, 141.9, 166.6; HRMS (ES): Found 310.1797; calc. 310.1792 for $\mathrm{C}_{20} \mathrm{H}_{24} \mathrm{NO}_{2}(\mathrm{M}+\mathrm{H})^{+}$.

(R)-2-((R)-1-((Benzyloxy)amino)ethyl)-5-phenylpentanoic acid (8). $1 \mathrm{M} \mathrm{NaOH}(0.40 \mathrm{~mL}, 0.40 \mathrm{mmol})$ was added to a solution of $7(32.0 \mathrm{mg}, 0.10 \mathrm{mmol})$ in 1,4-dioxane $(0.3 \mathrm{M})$ at room temperature and stirred overnight. The solution was extracted with hexane, the aqueous layer acidified to pH3 using $0.5 \mathrm{M}$ acetic acid, which was then extracted with EtOAc (three times), filtered over $\mathrm{MgSO}_{4}$ and the solvent removed to produce 8 (25.0 mg, 75\%) as a yellow oil. The acid was deemed sufficiently pure from ${ }^{1} \mathrm{H}$ NMR analysis and used in the next step without further purification. Rf (Hex/EtOAc 8:2) 0.33; $[\alpha]_{D}^{20}=-16.5^{\circ},\left(\mathrm{CH}_{2} \mathrm{Cl}_{2}, c=0.5\right) ; \mathrm{IR} v_{\max }(\mathrm{ATR}) / \mathrm{cm}^{-1} 1726$ $(\mathrm{C}=0) ; \delta_{\mathrm{H}}\left(300 \mathrm{MHz}, \mathrm{CDCl}_{3}\right) 1.09(\mathrm{~d}, J 6.6 \mathrm{~Hz}, 3 \mathrm{H}), 1.51-1.62(\mathrm{~m}, 4 \mathrm{H}), 2.43-2.56(\mathrm{~m}, 3 \mathrm{H}), 3.28-3.36(\mathrm{~m}, 1 \mathrm{H})$, $4.67(\mathrm{~s}, 2 \mathrm{H}), 7.14-7.34(\mathrm{~m}, 10 \mathrm{H}) ; \delta_{\mathrm{C}}\left(101 \mathrm{MHz} \mathrm{CDCl}_{3}\right)$ 16.0, 27.9, 29.3, 35.9, 49.2, 57.1, 76.5, 125.9, 128.1, 128.5, 128.5, 128.5, 128.6, 137.6, 142.1, 177.7; HRMS (ES): Found 328.1833; calc. 328.1835 for $\mathrm{C}_{20} \mathrm{H}_{26} \mathrm{NO}_{3}$ $(\mathrm{M}+\mathrm{H})^{+}$.

(R)-2-((R)-1-( $\boldsymbol{N}$-(Benzyloxy)formamido)ethyl)-5-phenylpentanoic acid (9). To a solution of 8 (0.25 g, 0.76 $\mathrm{mmol})$ in THF $(0.3 \mathrm{M})$ at $-10{ }^{\circ} \mathrm{C}$ was added pyridine $(0.25 \mathrm{~mL}, 3.04 \mathrm{mmol})$ and formic acetic anhydride $(3 \mathrm{~mL})$ (from heating formic acid and acetic anhydride at $55^{\circ} \mathrm{C}$ for $4 \mathrm{hr}$ ). The resulting solution was stirred at $-10{ }^{\circ} \mathrm{C}$ for $2 \mathrm{hr}$, after which the THF was removed in vacuo and the resulting residue dissolved in EtOAc and washed with $1 \mathrm{M} \mathrm{HCl}$ and sat. $\mathrm{NaCl}$. The organic layer was collected, filtered over $\mathrm{MgSO}_{4}$ and the solvent removed to give $9(0.22 \mathrm{~g}, 82 \%)$ as a yellow oil and a single geometrical isomer according to ${ }^{1} \mathrm{H}$ NMR spectroscopy. The acid was used in the next step without any further purification. $\mathrm{R}_{f}(\mathrm{DCM} / \mathrm{MeOH} 9.2: 0.8) 0.36 ;[\alpha]_{D}^{20}=-15.7^{\circ}$, $\left(\mathrm{CH}_{2} \mathrm{Cl}_{2}, c=0.5\right)$; IR $v_{\max }(\mathrm{ATR}) / \mathrm{cm}^{-1} 1682,1722(2 \times \mathrm{C}=0) ; \delta_{\mathrm{H}}\left(300 \mathrm{MHz}, \mathrm{CDCl}_{3}\right) 1.29(\mathrm{~d}, J 6.6 \mathrm{~Hz}, 3 \mathrm{H}), 1.60-1.75$ $(\mathrm{m}, 4 \mathrm{H}), 2.52-2.68(\mathrm{~m}, 3 \mathrm{H}), 2.85-2.92(\mathrm{~m}, 1 \mathrm{H}), 4.99(\mathrm{~s}, 2 \mathrm{H}), 7.17-7.37(\mathrm{~m}, 10 \mathrm{H}), 8.15(\mathrm{br} \mathrm{s}, 1 \mathrm{H}) ; \delta_{\mathrm{C}}(101$ $\left.\mathrm{MHz}_{1} \mathrm{CDCl}_{3}\right)$ 16.1, 28.7, 29.0, 35.7, 45.0, 50.9, 76.4, 126.1, 128.6, 128.6, 128.8, 129.1, 129.5, 135.0, 141.7, 159.4, 177.1; HRMS (ES): Found 356.1801; calc. for $\mathrm{C}_{21} \mathrm{H}_{26} \mathrm{NO}_{4} 356.1792(\mathrm{M}+\mathrm{H})^{+}$. 
(R)-2-(tert-Butoxycarbonylamino)-3,3-dimethylbutanoic acid. ${ }^{18}$ Di-tert-butyl dicarbonate $(1.82 \mathrm{~g}, 8.38 \mathrm{mmol})$ and $\mathrm{KOH}(1.16 \mathrm{~g}, 8.38 \mathrm{mmol})$ were added to a solution of L-tert-leucine $(1.00 \mathrm{~g}, 7.62 \mathrm{mmol})$ in $\mathrm{H}_{2} \mathrm{O}: \mathrm{THF}(4: 1,30$ $\mathrm{mL}$ ) and stirred at room temperature for $12 \mathrm{hr}$. THF was removed in vacuo and the resulting solution washed once with EtOAc. The aqueous layer was then acidified to $\mathrm{pH} 2$ with $1 \mathrm{M} \mathrm{HCl}$ and re-extracted with EtOAc $(3 \mathrm{x}$ $30 \mathrm{~mL}$ ). The combined organic layers were filtered over $\mathrm{MgSO}_{4}$ and reduced to produce $(R)$-2-(tertbutoxycarbonylamino)-3,3-dimethylbutanoic acid (1.53 g, 87\%) a white solid. Mp $119-121^{\circ} \mathrm{C}$ (Lit. Mp $118-$ $\left.121^{\circ} \mathrm{C}\right) ;^{18}[\alpha]_{D}^{20}=+5.2^{\circ},($ EtOAc, $c=1)\left(\right.$ Lit $[\alpha]_{D}^{24}=+5.8^{\circ},($ EtOAc, $c=0.6) i^{18} \mathrm{IR} v_{\max }(\mathrm{KBr}) / \mathrm{cm}^{-1} 1673,1720(2 \mathrm{x}$ $\mathrm{C}=\mathrm{O}), 2970(\mathrm{OH}), 3345(\mathrm{NH}) ; \delta_{\mathrm{H}}\left(400 \mathrm{MHz}, \mathrm{CDCl}_{3}\right) 1.01(\mathrm{~s}, 9 \mathrm{H}), 1.44(\mathrm{~s}, 9 \mathrm{H}), 4.12(\mathrm{~d}, J 8.1 \mathrm{~Hz}, 1 \mathrm{H}), 5.11(\mathrm{~d}, J 8.1$ $\mathrm{Hz}, 1 \mathrm{H}), 9.82$ (br s, $1 \mathrm{H}) ; \delta_{\mathrm{C}}\left(101 \mathrm{MHz} \mathrm{CDCl}_{3}\right)$ 26.7, 28.4, 34.6, 61.8, 80.2, 155.8, 176.7.

(R)-tert-Butyl 3,3-dimethyl-1-(methylamino)-1-oxobutan-2-ylcarbamate. ${ }^{18}$ To a solution of $(R)$-2-(tertbutoxycarbonylamino)-3,3-dimethylbutanoic acid $(2.00 \mathrm{~g}, 8.64 \mathrm{mmol})$ and HOBt (1.52 $\mathrm{g}, 11.2 \mathrm{mmol})$ in DCM $(24 \mathrm{~mL})$ at $0{ }^{\circ} \mathrm{C}$ was added $\mathrm{EDC} . \mathrm{HCl}(2.15 \mathrm{~g}, 11.2 \mathrm{mmol})$, methylamine. $\mathrm{HCl}(0.70 \mathrm{~g}, 10.4 \mathrm{mmol})$ and $\mathrm{Et}_{3} \mathrm{~N}(3 \mathrm{~mL}$, $21.6 \mathrm{mmol}$ ). The reaction mixture was stirred at $0{ }^{\circ} \mathrm{C}$ for 30 minutes, then warmed to room temperature and stirred overnight. The reaction was quenched with sat. $\mathrm{NH}_{4} \mathrm{Cl}$, extracted with $\mathrm{DCM}(3 \times 50 \mathrm{~mL})$ and the organic extracts washed with sat. $\mathrm{NaCl}$, filtered over $\mathrm{MgSO}_{4}$ and purified by flash chromatography to afford $(R)$-tertbutyl 3,3-dimethyl-1-(methylamino)-1-oxobutan-2-ylcarbamate (1.90 g, 90\%) as a white solid Mp $127-129{ }^{\circ} \mathrm{C}$ (Lit. Mp $\left.129^{\circ} \mathrm{C}\right) ;^{18}[\alpha]_{D}^{20}=+16.0^{\circ}$, (EtOAc, $\left.c=1\right)\left(\right.$ Lit. $[\alpha]_{D}^{24}=+13.4^{\circ}$, (EtOAc, $\left.c=1\right) ;^{18} \mathrm{IR} v_{\max }(\mathrm{KBr}) / \mathrm{cm}^{-1} 1679$, $1709(2 \times \mathrm{C}=0), 3099,3322(2 \times \mathrm{NH}) ; \delta_{\mathrm{H}}\left(400 \mathrm{MHz}, \mathrm{CDCl}_{3}\right) 0.98(\mathrm{~s}, 9 \mathrm{H}) 1.42(\mathrm{~s}, 9 \mathrm{H}), 2.78(\mathrm{~d}, \mathrm{~J} 4.8 \mathrm{~Hz}, 3 \mathrm{H}), 3.85(\mathrm{~d}$, J $9.4 \mathrm{~Hz}, 1 \mathrm{H}), 5.31$ (br s, $1 \mathrm{H}), 6.21(\mathrm{~s}, 1 \mathrm{H}) ; \delta_{\mathrm{C}}\left(101 \mathrm{MHz}, \mathrm{CDCl}_{3}\right)$ 26.0, 26.7, 28.5, 34.6, 62.4, 79.7, 156.1, 171.7.

(S)-2-Amino-N,3,3-trimethylbutanamide (10). ${ }^{18}$ Trifluoroacetic acid $(1.40 \mathrm{~mL}, 18.3 \mathrm{mmol})$ was added to a solution of $(R)$-tert-butyl 3,3-dimethyl-1-(methylamino)-1-oxobutan-2-ylcarbamate (0.20 g, $0.82 \mathrm{mmol})$ in DCM $(7 \mathrm{~mL})$ at $0{ }^{\circ} \mathrm{C}$. The reaction was allowed to warm to room temperature and stirred for $3 \mathrm{hr} ; \operatorname{cold~} 1 \mathrm{M} \mathrm{NaOH}(8$ $\mathrm{mL}$ ) was added and the $\mathrm{pH}$ was adjusted to $\mathrm{pH} 10$ and the organic material extracted into $\mathrm{DCM}(3 \times 30 \mathrm{~mL})$. The combined organic layers were filtered over $\mathrm{MgSO}_{4}$ and reduced to produce $10(0.101 \mathrm{~g}, 86 \%)$ as a yellow solid (recrystallised from DCM and hexane). Mp $121-123{ }^{\circ} \mathrm{C}$ (Lit. Mp $\left.123{ }^{\circ} \mathrm{C}\right) ;^{18}[\alpha]_{D}^{20}=52.1^{\circ},\left(\mathrm{H}_{2} \mathrm{O}, \mathrm{C}=0.5\right)(\mathrm{Lit}$. $[\alpha]_{D}^{20}=52.0^{\circ},\left(\mathrm{H}_{2} \mathrm{O}, c=0.5\right)^{18} ; \mathrm{IR} v_{\max }(\mathrm{KBr}) / \mathrm{cm}^{-1} 1677(\mathrm{C}=\mathrm{O}) ; \delta_{\mathrm{H}}\left(400 \mathrm{MHz}, \mathrm{CDCl}_{3}\right) 0.97(\mathrm{~s}, 9 \mathrm{H}), 1.73(\mathrm{br} \mathrm{s}, 2 \mathrm{H})$, $2.77(\mathrm{~d}, J 4.9 \mathrm{~Hz}, 3 \mathrm{H}), 3.04(\mathrm{~s}, 1 \mathrm{H}), 6.77(\mathrm{br} \mathrm{s}, 1 \mathrm{H}) ; \delta_{\mathrm{C}}\left(101 \mathrm{MHz}, \mathrm{CDCl}_{3}\right)$ 25.8, 26.8, 34.2, 64.5, 174.3.

\section{$(R)-2-((R)-1-(N-(B e n z y l o x y) f o r m a m i d o) e t h y l)-N-((R)-3,3-d i m e t h y l-1-(m e t h y l a m i n o)-1-o x o b u t a n-2-y l)-5-$}

phenylpentanamide (11). To a solution of 9 (180 mg, $0.51 \mathrm{mmol})$ in DCM (0.3 M) at $0{ }^{\circ} \mathrm{C}$ was added HOBt (90.0 $\mathrm{mg}, 0.66 \mathrm{mmol}), \mathrm{DCC}(140 \mathrm{mg}, 0.66 \mathrm{mmol}), 10$ (110 mg, $0.77 \mathrm{mmol})$ and DMAP (30.0 mg, $0.26 \mathrm{mmol})$. The reaction was allowed to warm to room temperature and stirred for a further $12 \mathrm{hr}$, filtered through Celite and the solvent evaporated in vacuo, and subjected directly to column chromatography to afford 11 (160 mg, 65\%) as a colourless solid (recrystallised from methanol and water). $\mathrm{Mp} 177-179{ }^{\circ} \mathrm{C} ; \mathrm{R}_{f}(\mathrm{DCM} / \mathrm{MeOH}$ 9.8:0.2) 0.64; $[\alpha]_{D}^{20}=-1.3^{\circ},\left(\mathrm{CH}_{3} \mathrm{OH}, c=0.2\right) ; \mathrm{IR} v_{\max }(\mathrm{ATR}) / \mathrm{cm}^{-1} 1674,1685,1697(3 \times \mathrm{C}=0) ; \delta_{\mathrm{H}}\left(300 \mathrm{MHz}, \mathrm{CD}_{3} \mathrm{OD}\right) 0.92(\mathrm{~s}$, $9 \mathrm{H}), 1.36(\mathrm{~d}, J 6.8 \mathrm{~Hz}, 3 \mathrm{H}), 1.48-1.64(\mathrm{~m}, 4 \mathrm{H}), 2.48-2.65(\mathrm{~m}, 5 \mathrm{H}), 2.73-2.85(\mathrm{~m}, 1 \mathrm{H}), 3.90-4.03(\mathrm{~m}, 1 \mathrm{H})$, $4.17(\mathrm{~s}, 1 \mathrm{H}), 4.88(\mathrm{~d}, J 9.2 \mathrm{~Hz}, 1 \mathrm{H}), 5.23(\mathrm{~d}, J 9.2 \mathrm{~Hz}, 1 \mathrm{H}), 7.12-7.53(\mathrm{~m}, 10 \mathrm{H}), 7.93(\mathrm{br} s, 1 \mathrm{H}) ; \delta_{\mathrm{C}}(101 \mathrm{MHz}$, $\left.\mathrm{CD}_{3} \mathrm{OD}\right) 17.3,26.1,27.5,30.1,31.3,35.2,36.9,43.1,51.3,62.5,79.3,127.0,129.5,129.6,129.7,130.0,130.7$, 136.7, 143.5, 160.6, 173.4, 175.7; Anal. Calc. for $\mathrm{C}_{28} \mathrm{H}_{39} \mathrm{~N}_{3} \mathrm{O}_{4}$ (\%): C, 69.83; $\mathrm{H}, 8.16 ; \mathrm{N}, 8.72$; Found (\%): C, 69.88; $\mathrm{H}, 8.18$; N, 8.69; HRMS (ES): Found 482.3014; calc. for $\mathrm{C}_{28} \mathrm{H}_{40} \mathrm{~N}_{3} \mathrm{O}_{4} 482.3019(\mathrm{M}+\mathrm{H})^{+}$. 


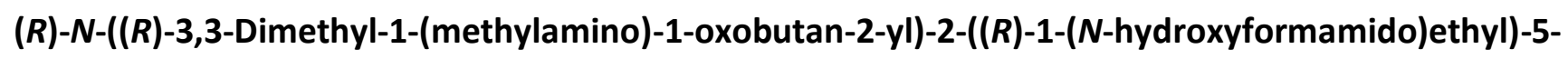

phenylpentanamide (12). To a solution of 11 (100 mg, $0.21 \mathrm{mmol})$ in $\mathrm{MeOH}(0.3 \mathrm{M})$ at room temperature was added $\mathrm{Pd} / \mathrm{C}$ (10 mol\%, $2.25 \mathrm{mg}, 0.02 \mathrm{mmol}$ ) and stirred under an $\mathrm{H}_{2}$ atmosphere for $3-6 \mathrm{hr}$ at room temperature. The suspension was filtered through Celite, which was washed with $\mathrm{MeOH}$ and the filtrate evaporated in vacuo and subjected directly to column chromatography to afford 12 (80.2 $\mathrm{mg}$, 97\%) as an orange solid, as a 5:2 mixture of hydroxamate geometrical isomers. $\mathrm{Mp} 123-125{ }^{\circ} \mathrm{C} ; \mathrm{R}_{f}(\mathrm{DCM} / \mathrm{MeOH}$ 9.8:0.2) 0.55; $[\alpha]_{D}^{20}=-4.0^{\circ},\left(\mathrm{CH}_{3} \mathrm{OH}, c=0.1\right) ; \mathrm{IR} v_{\max }(\mathrm{ATR}) / \mathrm{cm}^{-1} 1667,1678,1694(3 \times \mathrm{C}=0) ; \delta_{\mathrm{H}}\left(300 \mathrm{MHz}, \mathrm{CD}_{3} \mathrm{OD}\right) 0.96$ and $0.99(\mathrm{~s}, 9 \mathrm{H}, t$-butyl), 1.23 and $1.29(\mathrm{~d}, J 6.8 \mathrm{~Hz}, 3 \mathrm{H}, \mathrm{H}-8), 1.48-1.62(\mathrm{~m}, 4 \mathrm{H}), 2.49-2.65(\mathrm{~m}, 5 \mathrm{H}), 2.80-2.90$ $(\mathrm{m}, 1 \mathrm{H}, \mathrm{H}-5), 3.93$ and $4.55(\mathrm{~m}, 1 \mathrm{H}, \mathrm{H}-6), 4.23(\mathrm{~s}, 1 \mathrm{H}, \mathrm{H}-3), 7.10-7.25(\mathrm{~m}, 5 \mathrm{H}), 7.80$ and $7.96(\mathrm{~s}, 1 \mathrm{H}, \mathrm{H}-7) ; \delta_{\mathrm{c}}$ (101 MHz, CD $\mathrm{CD}_{3} \mathrm{O} 15.8$ and 16.5 (C-8), 26.2, 27.4 (t-butyl, C-17), 30.2, 31.0, 35.3, 36.9, 44.7 and 53.4 (C-5), 51.0 and 58.6 (C-6), 62.4 (C-3), 127.0, 129.5, 129.6, 143.5, 159.0 and 163.1 (C-7), 173.3, 175.9; Anal. Calc. for $\mathrm{C}_{21} \mathrm{H}_{33} \mathrm{~N}_{3} \mathrm{O}_{4}$ (\%): C, 64.42; $\mathrm{H}, 8.50 ; \mathrm{N}, 10.73$; Found (\%): C, 64.51; H, 8.56 N, 10.81; HRMS (ES): Found 392.2546, calc. for $\mathrm{C}_{21} \mathrm{H}_{34} \mathrm{~N}_{3} \mathrm{O}_{4} 392.2549(\mathrm{M}+\mathrm{H})^{+}$; Chiral HPLC analysis on a Chiracel OD column with the eluent composed of Hex (60\%): $i-\mathrm{PrOH}(40 \%)$, for $20 \mathrm{~min}$ with a flow rate of $1 \mathrm{~mL} / \mathrm{min}$ at $\lambda=254 \mathrm{~nm}$ produced a single peak at $\mathrm{t}_{\mathrm{r}}$ $=16.3 \mathrm{~min}$ (96\%); HPLC analysis on a C18 reverse phase column with the eluent composed of $1 \%$ TFA in $\mathrm{H}_{2} \mathrm{O}$ (A) and acetonitrile (B) with a gradient: 30 to $90 \%$ B within 12 min and $100 \%$ B for 6 min with a flow rate of 1 $\mathrm{mL} / \mathrm{min}$, at $\lambda=215 \mathrm{~nm}$ produced a single peak at $\mathrm{t}_{\mathrm{r}}=5.4 \mathrm{~min}(99 \%)$.

\section{Acknowledgements}

The authors would like to thank the Nuclear Technologies in Medicine and the Biosciences Initiative (NTeMBI), for their funding. NTeMBI is a national technology platform developed and managed by the South African Nuclear Energy Corporation (Necsa) and funded by the South African Department of Science and Technology. The financial assistance of the South African National Research Foundation (NRF) towards this research is hereby acknowledged. Opinions expressed, and conclusions arrived at, are those of the authors and are not necessarily to be attributed to the NRF.

\section{Supplementary Material}

Copies of ${ }^{1} \mathrm{H}$ and ${ }^{13} \mathrm{C}$ NMR spectra of compounds 1, 3-12 are given in the Supplementary Material file associated with this article.

\section{References}

1. Parkin, E.; Harris, B. J. Neurochem. 2009, 1464.

http://doi:10.1111/j.1471-4159.2009.05907.x.

2. Chen, A. Y.; Adamek, R. N.; Dick, B. L.; Credille, C. V.; Morrison, C. N.; Cohen, S. M. Chem. Rev. 2019, 119, 1323.

2. http:// doi:10.1021/acs.chemrev.8b00201

3. Andrews, R. C.; Andersen, M. W.; Cowan, D. J.; Deaton, D. N.; Dickerson, S. H.; Drewry, D. H..; Gaul, D. M.; Luzzio, M.; Marron, B. E.; Rabinowitz, M. H. Preparation of peptidyl formamide compounds as therapeutic 
agents. WO2000012083, 2001.

4. Bae, Y. H.; Mrsny, R. J.; Park, K. Cancer Targeted Drug Delivery: An Elusive Dream; Springer, Ed.; New York, 2013.

5. Beckett, P. R.; Launchbury, S.; Pain, G.; Pratt, L. M. N-Formyl hydroxylamine derivatives as inhibtiors of bacterial polypeptide formylase for treating microbial infections. W00241886. WO02/41886, 2007.

6. Wardenburg, J. B.; Schmalzer, K. Methods and compositions using Adam 10 inhibitors to treat bacterial infection WO165746A1, 2014.

7. Hoettecke, N.; Ludwig, A.; Foro, S.; Schmidt, B. Neurodegenerative Dis., 2010, 4, 232-238. http://doi: 10.1159/000267865

8. Evans, D. A. Aldrichimica Acta. 1982, 15 (2), 23.

9. Evans, D. A.; Bartroli, J.; Shih, T. L. J. Am. Chem. Soc 1981, 8, 2127. https://doi.org/10.1021/ja00398a058

10. Shinisha, C. B.; Sunoj, R. B. J. Am. Chem. Soc. 2010, 132, 12319. https://doi.org/10.1021/ja101913k

11. Ager, D. J.; Prakash, I.; Schaad, D. R. Aldrichimica Acta. 1997, 30, 3.

12. Heravi, M. M.; Zadsirjan, V. Tetrahedron: Asymmetry 2013, 24, 1149. https://doi.org/10.1016/j.tetasy.2013.08.011

13. Evans, D. A.; Helmchen, G.; Rueping, M. Asymmetric Synthesis-The Essentials, Wiley-VCH, Weinheim, 2007. 14. Cowden, C.J.; Paterson, I. Org. React. 1997, 51, 1. https://doi.org/10.1002/0471264180.or051.01

15. Gage, R.; Evans, D. A. Org. Syn. 1990, 68, 83. https://doi.org/10.15227/orgsyn.068.0083

16. Evans, D. A.; Nelson, J. V.; Vogel, E.; Taber, T. R. J. Am. Chem. Soc. 1981, 103, 3099. https://doi.org/10.1021/ja00401a031

17. Singh, N.; Karpichev, Y.; Sharma, R.; Gupta, B.; Sahu, A. K.; Satnami, M. L.; Ghosh, K. K. Org. Biomol. Chem. 2015, 13, 2827. https://doi.org/10.1039/C4OB02067G

18. Jenssen, K.; Sewald, K.; Sewald, N. Bioconjug. Chem. 2004, 15, 594. https://doi.org/10.1021/bc034225I

19. Munshi, P.; Padmanabhan, S.; Sullivan, S. Z.; Mustafa, T. A.; Brezden, A. M.; Ghosh, A. Part. Sci. Technol. An Int. J. 2011, 37. https://doi.org/10.1080/02726351.2010.510550

20. Sigma-Aldrich. (R)-4-Benzyl-2-oxazolidinone MSDS. Safety Data Sheet; 2012.

21. Lynch, E. T.; McCall, E. B. J. Chem. Soc., 1960, 1254-1262.

https://doi.org/10.1039/JR9600001254

This paper is an open access article distributed under the terms of the Creative Commons Attribution (CC BY) license (http://creativecommons.org/licenses/by/4.0/) 